\title{
Correction to: Canopy dynamics in a tropical Atlantic forest mosaic in southeastern Brazil
}

\author{
Flávia P. Nunes ${ }^{1}$ - Silvana A. B. Castro' ${ }^{1}$ J. P. Lemos-Filho ${ }^{2}$ Queila S. Garcia ${ }^{2}$
}

Published online: 30 June 2020

(c) Botanical Society of Sao Paulo 2020

\section{Correction to: Brazilian Journal of Botany https://doi.org/10.1007/s40415-020-00592-w}

In the initial online publication, the name of the third author was missing. The original article has been corrected.

Publisher's Note Springer Nature remains neutral with regard to jurisdictional claims in published maps and institutional affiliations.

The original article can be found online at https://doi.org/10.1007/ s40415-020-00592-w.

\footnotetext{
Flávia P. Nunes

flavia@razaoambiental.com.br

1 Programa de Pós-Graduação Ecologia, Conservação e Manejo da Vida Silvestre, ICB, UFMG, Belo Horizonte, Brazil

2 Departamento de Botânica, ICB, Universidade Federal de Minas Gerais, Caixa postal 486, Belo Horizonte, MG CEP 31270-970, Brazil
} 